\title{
Fatty Acid Composition of Porcine Muscle and Adipose Tissue Lipids as Affected by Anatomical Location and Cod Liver Oil Supplementation of the Diet
}

\author{
By $O$. Taugb $\phi l^{1}$ and K. Saarem ${ }^{2}$ \\ ${ }^{1}$ Department of Biochemistry, Physiology and Nutrition, Norwegian College of Veterinary Medicine, and \\ ${ }^{2}$ Peter Möller avd. av ORKLS A.S., Oslo, Norway.
}

\begin{abstract}
Taugbøl, O. and K. Saarem: Fatty acid composition of porcine muscle and adipose tissue lipids as affected by anatomical location and cod liver oil supplementation of the diet. Acta vet. scand. 1995, 36, 93-101. - In pigs fed a standard pig mash the contents of polyunsaturated fatty acids (PUFAs) of both the n-6 and n-3 series were significantly higher in the dark red $\mathrm{mm}$ adductores compared to the light coloured $m$ longissimus lumborum. Perirenal fat had a higher concentration of saturated fatty acids (14:0, 16:0, 18:0) than backfat, and a lower concentration of monounsaturated fatty acids, such as 16:1n-7 and 18:1n-9. Daily supplementation of $50 \mathrm{ml}$ cod liver oil, rich in n-3 PUFAs, during the fourth and third week before slaughter led to a 1.4 to 1.7 times increase in the contents of n-3 PUFAs in muscles and fat depots. There was no difference between the incorporation of n-3 PUFAs in dark and light muscles. Perirenal fat contained more 20:5n-3 (EPA) and 22:6n-3 (DHA), but less 20:1n-9 (eicosenoic acid) than the backfat, after cod liver oil supplementation rich in these 3 fatty acids. Supplementation of cod liver oil reduced the $n-6 / n-3$ fatty acid ratio in all anatomical locations examined.
\end{abstract}

fish oil; meat quality.

\section{Introduction}

Polyunsaturated fatty acids (PUFAs), especially the n-3 PUFA eicosapentaenoic acid (EPA; 20:5n-3) and docosahexaenoic acid (DHA; 22:6n-3), are currently of great interest due to their important biological functions (Simopoulos 1991). The n-3 PUFAs are found in abundance in sea food like fish oil (cod liver oil), but are scarce in fat from grain fed animals. Pigs supplemented with fish oil incorporate n-3 PUFAs into depot fat after a few days in a dose dependent manner (Irie \& Sakimoto 1992, Taugbøl 1993). Pigs fed a supplementation of fish oil for 4 weeks until the day of slaughter, showed some differences in the dis- tribution of the supplemented fatty acids to perirenal fat and subcutaneous fat (Irie \& Sakimoto 1992). Intramuscular fat showed a delayed rise in n-3 PUFAs content compared to depot fat (Taugbøl 1993). Malmfors et al. (1978) reported that the dark muscles, which are associated with aerobic muscle fibres, contained a higher proportion of the PUFAs: $18: 2 n-6,18: 3 n-3$ and $20: 4 n-6$, than the light muscles of normal fed pigs. It is not known whether incorporation of n-3 PUFAs differ in dark and light muscles, or if fish oil supplementation will change the fatty acid pattern in muscle lipids. 
Table 1. Composition of the standard diet (\%).

\begin{tabular}{lc}
\hline Component & $\%$ \\
\hline Barley grain & 40.2 \\
Oat meal & 40.0 \\
Meat and bone meal & 6.0 \\
Wheat bran & 5.0 \\
Soybean meal, solvent extracted & 2.63 \\
Animal fat & 1.5 \\
Rapeseed meal (Canola) & 1.2 \\
Fish meal, herring & 1.0 \\
Molasses & 1.0 \\
Limestonemeal & 0.5 \\
Salt & 0.25 \\
Trace mineral mix* & 0.1 \\
Vitaminpremix** & 0.4 \\
L-lysine & 0.16 \\
L-threonine & 0.06 \\
\hline Calculated composition & \\
Crude protein & 15.4 \\
Crude fat & 5.4 \\
Calcium & 0.8 \\
Phosphorus & 0.62 \\
ME, MJ/kg & 12.32 \\
\hline
\end{tabular}

* Contained the following trace minerals: $\mathrm{Fe} 5 \%$, Mn 4\%, Zn 7\%, Cu 1\%, I .05\%, Se .02\%.

** Provided the following per kg. of diet: vitamin A 3000 IU, vitamin D3 400 IU, vitamin E $40 \mathrm{mg}$, vitamin B2 $3 \mathrm{mg}$, vitamin B12 $0.02 \mathrm{mg}$, pantothenic acid $10 \mathrm{mg}$.

The present experiment was undertaken to provide information about the fatty acid pattern, with special reference to the n-3 PUFAs in different muscles and in different fat depots of pigs fed a standard pig mash, and to test if supplementation with cod liver oil will change the fatty acid distribution in these tissues.

\section{Materials and methods}

\section{Animals and diets}

Two trials involving 30 Norwegian Landrace (Sus scrofa f. domestica) barrows and gilts were conducted. The pigs were delivered to a commercial slaughterhouse at approximately
$100 \mathrm{~kg}$ live weight. In trial I all pigs were fed exclusively a standard pig mash (Table 1). In trial II 6 pigs out of 12 received a supplement of $50 \mathrm{ml}$ cod liver oil (Peter Möller, Norway), from which vitamin $A$ and $D$ have been removed by molecular distillation, every day during the fourth and third week before slaughter. The other 6 pigs, referred to as the control group, were fed only the standard pig mash. The amount of pig mash fed was $3 \mathrm{~kg}$ daily the last 4 weeks before slaughter in both trials. Adding $50 \mathrm{ml}$ cod liver oil for 2 weeks led to an about $5 \%$ higher daily energy intake in the supplemented group compared to the control group. Although this might have resulted in a slightly higher weight gain, the primary objective of this trial was to study the changes of the fatty acid pattern in muscle and fat tissues after a supplementation with cod liver oil. The fatty acid composition of the basal diet and the cod liver oil is given in Table 2.

\section{Experimental procedure}

Two parallel samples were taken from the dark red $m m$ adductores, the light $m$ longissimus lumborum and the red $m$ psoas minor from each pig. In trial II samples from the backfat, including both outer and inner layers, and perirenal fat were also included. The samples, weighing 400-600 mg, were stored in small plastic tubes containing $0.9 \%$ saline solution at $-80^{\circ} \mathrm{C}$ until analysed.

A part of each sample $(150 \mathrm{mg})$ was homogenized for $2 \mathrm{~min}$ in a $3 \mathrm{ml}$ mixture of chloroform and methanol (2:1). Thereafter, $0.6 \mathrm{ml}$ isotonic saline solution was added and the content homogenized for $30 \mathrm{sec}$ (Folch et al. 1957). The homogenate was then filtered through purified cotton wool, and stored at $-20^{\circ} \mathrm{C}$ until the next day. The aqueous phase was removed and the extract was placed in a waterbath at $45^{\circ} \mathrm{C}$ and evaporated under nitrogen. To the residue $5 \mathrm{ml}$ methanol with 2 
vol \% sulfuric acid was added, before placing it in a waterbath at $80^{\circ} \mathrm{C}$ for $3 \mathrm{~h}$ for methylation.

The methylated fatty acids were extracted with $1 \mathrm{ml}$ heptane and separated on a fused silica wall coated capillary column (Omegawax $320,30 \mathrm{~m} \times 0.32 \mathrm{~mm}$, film thickness 0.25 $\mathrm{mm}$ (Supelco Inc, Bellefonte) in a Perkin Elmer 8400 gas chromatograph fitted with a flame-ionization detector and a programmable temperature vaporizer (PTV) injector. The samples were injected at splitless condition by an autosampler (Perkin Elmer AS3000). Carrier gas was helium at a flow rate of $1.3 \mathrm{ml} / \mathrm{min}$. The injector and detector temperature was $275^{\circ} \mathrm{C}$. The column temperature was kept at $70^{\circ} \mathrm{C}$ for $2 \mathrm{~min}$, then increased to $170^{\circ} \mathrm{C}$ at a rate of $30^{\circ} \mathrm{C} / \mathrm{min}$, then up to $250^{\circ} \mathrm{C}$ at a rate of $4^{\circ} \mathrm{C} / \mathrm{min}$. This temperature was held for 10 to $15 \mathrm{~min}$. Peak areas were determined by The Omega-2 Integrator System (Perkin Elmer) by an Epson AX2-40 personal computer. Identification of major peaks was made by comparing the retention time with those of standard fatty acid methyl esters obtained from Supelco Inc, Bellefonte, or Sigma Chemical Co, USA.

Muscle samples from 10 other slaughtered pigs were used for fiber typing. The muscle samples from the $m m$ adductores, $m$ longissimus lumborum and $m$ psoas minor were frozen in Freon 22, pre-cooled to about its melting point (i.e. $-160^{\circ} \mathrm{C}$ ). The muscle samples (still frozen) were mounted in a mounting medium (Lab-Tek Products, Napersville, III., USA) on a metal plate and stored at $-80^{\circ} \mathrm{C}$. Serial cross sections $(10 \mathrm{~mm})$ were cut transversal to the fibre direction at $-20^{\circ} \mathrm{C}$. The sections were stained for myofibrillar ATPase after both acid and alkaline preincubation. The first procedure involved only 1 preincubation in an acid buffer ( $\mathrm{pH} 4.25$ ) containing $25 \mathrm{mM}$. $\mathrm{CaCl}_{2}$. In sections stained with this procedure
Table 2. Fatty acid composition (area\%) of standard diet and cod liver oil.

\begin{tabular}{lcc}
\hline Fatty acid & Standard diet & Cod liver oil ${ }^{*}$ \\
\hline $14: 0$ & 2.0 & 3.7 \\
$16: 0$ & 19.4 & 10.4 \\
$16: 1 \mathrm{n}-7$ & 2.0 & 8.0 \\
$18: 0$ & 3.7 & 2.2 \\
$18: 1 \mathrm{n}-9$ & 27.4 & 23.0 \\
$18: 2 \mathrm{n}-6$ & 37.6 & 1.6 \\
$18: 3 \mathrm{n}-3$ & 3.5 & 1.0 \\
$18: 4 \mathrm{n}-3$ & 0.3 & 2.6 \\
$20: 1 \mathrm{n}-9$ & 1.1 & 13.3 \\
$22: 1 \mathrm{n}-11 / 13$ & 0.5 & 7.7 \\
$20: 5 \mathrm{n}-3$ (EPA) & 0.3 & 9.7 \\
$22: 5 \mathrm{n}-3$ (DPA) & - & 1.1 \\
$22: 6 \mathrm{n}-3$ (DHA) & 0.5 & 12.7 \\
Not & & \\
accounted for & 1.7 & 3.0 \\
\hline
\end{tabular}

* Vitamin A: < $30 \mathrm{IU} / \mathrm{g} ;$ Vitamin D: < $1 \mathrm{IU} / \mathrm{g}$

type I fibres appeared dark in contrast to the light type II fibres. In the second procedure, sections were first preincubated in an alkaline buffer ( $\mathrm{pH} \mathrm{10.3)} \mathrm{containing} 75 \mathrm{mM} \mathrm{CaCl}_{2}$, fixed in formaldehyde and then preincubated in an acid buffer ( $\mathrm{pH} 4.6$ ) containing $20 \mathrm{mM}$ $\mathrm{CaCl}_{2}$. In these sections the type I fibres appeared light and the type II fibres appeared dark (Brook \& Kaiser 1970, Vøllestad et al. 1984). The fibre types were identified as type I and II fibres. Between 100 and 500 fibres were identified from each muscle sample.

\section{Statistical methods}

The results are described as the number of pigs $(\mathrm{N})$, the mean and standard deviation. For the evaluation of the muscle samples, where 2 replicate measurements within each pig were made, a repeated measures ANOVA was performed (Hand \& Taylor 1991). In case of a statistical significance, Tukey's multiple comparison procedure was performed to rank the responces (Montgomery 1984). For the 
Table 3. Fatty acid composition (area\%) of lipid fraction from $m$ m adductores, $m$ longissimus lumborum and $m$ psoas minor in pigs fed a standard pig mash $(\mathrm{n}=18)$.

\begin{tabular}{|c|c|c|c|c|c|c|c|}
\hline \multirow[b]{2}{*}{ Fatty acid } & \multicolumn{2}{|c|}{ Mm adductores } & \multicolumn{2}{|c|}{$\begin{array}{l}M \text { psoas } \\
\text { minor }\end{array}$} & \multicolumn{2}{|c|}{$\begin{array}{c}M \text { longissimus } \\
\text { lumborum }\end{array}$} & \multirow[b]{2}{*}{$\mathrm{p}<0.05$} \\
\hline & Mean & SD & Mean & SD & Mean & SD & \\
\hline $14: 0$ & 1.27 & .12 & 1.33 & .15 & 1.34 & .14 & \\
\hline $16: 0$ & 20.45 & .71 & 21.84 & .98 & 21.73 & 1.04 & \\
\hline $16: 1 n-7$ & 1.49 & .42 & 1.97 & .43 & 2.62 & .79 & a \\
\hline 18:0 & 11.06 & .62 & 12.16 & .99 & 11.22 & 1.05 & \\
\hline $18: 1 n-9$ & 21.05 & 4.26 & 28.54 & 3.99 & 33.04 & 5.87 & a \\
\hline $18: 1 n-7$ & 3.20 & .23 & 2.85 & .40 & 3.02 & .47 & \\
\hline $18: 2 n-6$ & 22.02 & 2.27 & 17.57 & 2.41 & 13.77 & 3.16 & $\mathrm{~b}$ \\
\hline $18: 3 n-3$ & 0.60 & .06 & 0.72 & .10 & 0.55 & .07 & \\
\hline $20: 1 n-9$ & 0.57 & .12 & 0.74 & .07 & 0.84 & .14 & c \\
\hline $20: 4 n-6$ & 6.41 & 1.08 & 3.66 & 1.09 & 3.43 & 1.62 & $\mathrm{~d}$ \\
\hline 20:5n-3 (EPA) & 0.57 & .11 & 0.33 & .09 & 0.31 & .15 & d \\
\hline $22: 5 n-3$ (DPA) & 0.84 & .13 & 0.61 & .16 & 0.59 & .24 & d \\
\hline $22: 6 n-3$ (DHA) & 0.76 & .21 & 0.49 & .15 & 0.50 & .23 & $\mathrm{~d}$ \\
\hline
\end{tabular}

a: $M$ longissimus lumborum $>M$ psoas minor $>M m$ adductores

b: $M m$ adductores $>M$ psoas minor $>M$ longissimus lumborum

c: $M$ longissimus lumborum and $M$ psoas minor $>M m$ adductores

$\mathrm{d}$ : $M m$ adductores $>M$ psoas minor and $M$ longissimus lumborum

lipid samples, with just 1 observation from each pig, an ANOVA was performed, with the position, the case number and the group as the class variables. The groups were compared with Dunnett's test. A complete model cheque was performed using the Jackknife residuals, Cook's d and Mallow's $\mathrm{C}_{\mathrm{p}}$ (Kleinbaum 1988). All p-values below 0.05 were considered significant.

Table 4. Muscle fibre composition (\%) of $\mathrm{mm}$ adductores, $m$ psoas minor and $m$ longissimus lumborum $(\mathrm{n}=10)$.

\begin{tabular}{|c|c|c|c|c|c|c|}
\hline \multirow[b]{2}{*}{ Fibre type } & \multicolumn{2}{|c|}{$\begin{array}{c}\text { Mm } \\
\text { adductores }\end{array}$} & \multicolumn{2}{|c|}{$\begin{array}{l}\text { M psoas } \\
\text { minor }\end{array}$} & \multicolumn{2}{|c|}{$\begin{array}{c}M \text { longissimus } \\
\text { lumborum }\end{array}$} \\
\hline & Mean & SD & Mean & SD & Mean & SD \\
\hline I & 22 & 6 & 16 & 14 & 20 & 3 \\
\hline II & 77 & 6 & 83 & 13 & 79 & 3 \\
\hline unident. & 1 & & 1 & & 1 & \\
\hline
\end{tabular}

\section{Results}

Muscles

In pigs fed a standard pig mash the contents of PUFAs (18:2n-6; 20:4n-6; 20:5n-3; 22:5n-3; $22: 6 \mathrm{n}-3)$ of the dark red $\mathrm{mm}$ adductores were significantly higher than in both $m$ psoas minor and the $m$ longissimus lumborum. The contents of 18:2n- 6 of the red $m$ psoas minor were significantly higher than for the light $m$ longissimus lumborum. The contents of the monounsaturated fatty acids $(16: 1 \mathrm{n}-7 ; 18: 1 \mathrm{n}$ $9 ; 20: 1 \mathrm{n}-9)$ were higher in the lipidfraction of $m$ longissimus lumborum and $m$ psoas minor than of mm adductores, and the 16:1n-7 and 18:1n-9 concentrations were higher in $m$ longissimus lumborum compared to $m$ psoas minor (Table 3).

There was no difference between the 3 muscles with regard to fibre composition (Table 4). After cod liver oil supplementation the n-3 
Table 5. Distribution (area\%) of n-3 PUFAs in lipid fractions of $m m$ adductores, $m$ psoas minor and $m$ longissimus lumborum from pigs fed a standard pig mash (control) $(\mathrm{n}=6)$ and pigs supplemented with cod liver oil (CLO) $(n=6)$.

\begin{tabular}{|c|c|c|c|c|c|c|c|c|}
\hline \multirow[b]{2}{*}{ Fatty acid } & \multirow[b]{2}{*}{ Group } & \multicolumn{2}{|c|}{$\begin{array}{c}\text { Mm } \\
\text { adductors }\end{array}$} & \multicolumn{2}{|c|}{$\begin{array}{l}\text { M psoas } \\
\text { minor }\end{array}$} & \multicolumn{3}{|c|}{$\begin{array}{l}M \text { longissimus } \\
\text { lumborum }\end{array}$} \\
\hline & & Mean & SD & Mean & SD & Mean & SD & $\mathrm{p}<0.05$ \\
\hline $20: 5 n-3$ & control & 0.60 & .15 & 0.42 & .16 & 0.29 & .16 & $\mathrm{a}$ \\
\hline (EPA) & CLO & 1.29 & .25 & 0.72 & .31 & 0.55 & .32 & $a, b$ \\
\hline $22: 5 n-3$ & control & 0.85 & .17 & 0.60 & .15 & 0.50 & .21 & a \\
\hline (DPA) & CLO & 1.06 & .16 & 0.72 & .19 & 0.68 & .37 & $a, b$ \\
\hline $22: 6 n-3$ & control & 0.82 & .30 & 0.61 & .22 & 0.40 & .17 & a \\
\hline (DHA) & CLO & 1.24 & .50 & 0.92 & .34 & 0.82 & .50 & $a, b$ \\
\hline
\end{tabular}

a: $M m$ adductores $>M$ psoas minor and $M$ longissimus lumborum.

b: $\mathrm{CLO}>$ Control.

PUFAs (EPA; DPA; DHA), were significantly higher than in the control group for all muscle samples (Table 5). Other fatty acids analyzed in the 3 muscles did not differ between the 2 groups. In both groups the contents of n-3 PUFAs were significantly higher in the $\mathrm{mm}$ adductores compared to the 2 other muscles.
Fat

In pigs fed the control diet perirenal fat was lower in 16:1n-7 and 18:1n-9 and higher in 16:0 than backfat. For the other 2 saturated fatty acids examined (14:0 and 18:0) statistical borderline values were found, with higher content in perirenal fat than in backfat (Table 6). Cod liver oil supplementation increased the

Table 6. Fatty acid composition (area $\%$ ) of backfat and perirenal fat in pigs fed a standard pig mash $(n=6)$.

\begin{tabular}{|c|c|c|c|c|c|}
\hline \multirow[b]{2}{*}{ Fatty acid } & \multicolumn{2}{|c|}{ Backfat } & \multicolumn{2}{|c|}{ Perirenal fat } & \multirow[b]{2}{*}{$\mathrm{p}<0.05$} \\
\hline & Mean & SD & Mean & SD & \\
\hline $14: 0$ & 1.19 & .10 & 1.28 & .06 & $(p=0.06)$ \\
\hline $16: 0$ & 21.35 & 1.22 & 23.63 & 1.34 & $\mathrm{a}$ \\
\hline $16: 1 n-7$ & 2.16 & .27 & 1.65 & .24 & b \\
\hline 18:0 & 18.54 & 4.12 & 24.18 & 5.41 & $(p=0.07)$ \\
\hline $18: 1 n-9$ & 36.35 & 3.16 & 27.26 & 3.12 & $\mathrm{~b}$ \\
\hline $18: 2 n-6$ & 14.15 & 2.07 & 15.65 & 2.92 & \\
\hline $18: 3 n-3$ & 0.96 & .10 & 1.03 & .15 & \\
\hline $20: 1 n-9$ & 1.22 & .08 & 1.16 & .11 & \\
\hline $20: 4 n-6$ & 0.28 & .09 & 0.27 & .07 & \\
\hline 20:5n-3 (EPA) & 0.06 & .01 & 0.06 & .01 & \\
\hline $22: 5 n-3$ (DPA) & 0.17 & .02 & 0.18 & .04 & \\
\hline $22: 6 n-3$ (DHA) & 0.17 & .03 & 0.22 & .06 & $(p=0.13)$ \\
\hline
\end{tabular}

a: Backfat $<$ Perirenal fat.

b: Backfat $>$ Perirenal fat. 
Table 7. Distribution (area\%) of 20:1n-9 and n-3 PUFAs in backfat and perirenal fat from pigs fed a standard pig mash (control) $(n=6)$ and pigs supplemented with cod liver oil (CLO) $(n=6)$.

\begin{tabular}{llllllll}
\hline & & \multicolumn{2}{c}{ Backfat } & & \multicolumn{2}{c}{ Perirenal fat } & \\
\cline { 3 - 3 } Fatty acid & Group & Mean & SD & & Mean & SD & $\mathrm{p}<0.05$ \\
\hline $20: 1 \mathrm{n}-9$ & Control & 1.22 & .08 & & 1.16 & .11 & \\
& CLO & 1.40 & .08 & & 1.27 & .08 & $\mathrm{a}, \mathrm{b}$ \\
$20: 5 \mathrm{n}-3$ & Control & 0.06 & .01 & & 0.06 & .01 & \\
(EPA) & CLO & 0.12 & .02 & & 0.14 & .02 & $\mathrm{a}, \mathrm{c}$ \\
$22: 5 \mathrm{n}-3$ & Control & 0.17 & .02 & & 0.18 & .04 & \\
(DPA) & CLO & 0.25 & .03 & & 0.26 & .02 & a \\
$22: 6 \mathrm{n}-3$ & Control & 0.17 & .03 & & 0.22 & .06 & \\
(DHA) & CLO & 0.30 & .03 & & 0.37 & .03 & $\mathrm{a}, \mathrm{c}$ \\
\hline
\end{tabular}

a: $\mathrm{CLO}>$ Control

b: Backfat $>$ Perirenal fat (CLO)

c: Backfat $<$ Perirenal fat (CLO)

contents of 20:1n-9 (eicosenoic acid) and n-3 PUFAs in both backfat and perirenal fat. The monounsaturated fatty acid 20:1n-9 was found in higher concentration in backfat than in perirenal fat, whereas EPA and DHA were higher in perirenal fat (Table 7).

\section{The ratio of $n-6 / n-3$ fatty acids}

The ratio of $n-6 / n-3$ fatty acids was calculated, based on the following fatty acids: $18: 2 \mathrm{n}-6$, $20: 4 n-6,18: 3 n-3,20: 5 n-3,22: 5 n-3$ and 22:6n-3. The ratio decreased in both fat and muscle tissues after cod liver oil supplementation (Table 8).

\section{Discussion}

In pigs fed a standard pig mash the contents of PUFAs of both the $n-6$ and n-3 series were significantly higher in the dark red $\mathrm{mm}$ adductores compared to the light $m$ longissimus lumborum. A similar difference in PUFAs with 18 and 20 carbon atoms was found between the dark $m$ quadriceps and the light $m$ longissimus dorsi (Malmfors et al. 1978), and between the red $m$ psoas major and the light $m$ longissimus dorsi (Allen et al. 1967). One would expect these differences to be due to differences in fibre composition in the tested muscles. The 3 muscles did not, however, differ with regard to type I and II fibres. Type I fibre is referred to as slow twitch fibre and type II as fast twitch fibre. Fast twitch fibres have high myofibrillar ATPase activity, and can be further divided into fast twitch fati-

Table 8 . Ratio n-6/n-3 fatty acid in different tissues from pigs fed a standard pig mash (control) and pigs supplemented with cod liver oil (CLO). The following fatty acids are considered: $18: 2 n-6$ and $20: 4 n-6 /$ $18: 3 n-3,20: 5 n-3,22: 5 n-3$ and $22: 6 n-3$.

\begin{tabular}{lrr}
\hline Group & Control & CLO \\
\hline Muscles & & \\
Mm adductores & 10.26 & 7.62 \\
M psoas minor & 9.87 & 7.52 \\
M longissimus lumborum & 8.82 & 6.47 \\
Fat depots & & \\
Backfat & 10.61 & 8.38 \\
Perirenal fat & 10.68 & 8.07 \\
\hline
\end{tabular}


gable and fast twitch fatigue-resistant. Fast twitch fatigable fibres fatigue rapidly due to, a low capacity for oxidative metabolism. These fibres have a low mitochondrial and myoglobin content. Fast twitch fatigue-resistant fibres, on the other hand, have a high content of both mitochondria and myoglobin, and therefore a high oxidative capacity. Slow twitch and fast twitch fatigue-resistant muscle fibres are both red in colour due to the high myoglobin content. Since the fibre identification in this study was based solely on ATPase stain, the type II fibres could not be subdivided. However, the dark, red colour of $\mathrm{mm}$ adductores indicates a large proportion of aerobic type fast twitch fatigue-resistant fibres with high mitochondrial content (Brook \& Kaiser 1970). PUFAs are preferably incorporated in the phospholipid fraction of membranes, rather than being converted by competing pathways, such as fatty acid oxidation and triacylglycerol synthesis (Iritani \& Narita 1984). Thus, the higher contents of n-3 and n-6 PUFAs in $m m$ adductores compared to $m$ longissimus lumborum may partly be due to a larger mitochondrial membrane area of the former. Although the contents of the individual n-3 PUFAs of the red $m$ psoas minor were not statistically different from those of the light $m$ longissimus lumborum, all the mean values of $m$ psoas minor were higher.

The fatty acid pattern of pork fat of control diet fed pigs was consistent with those reported by Villegas et al. (1973) and Irie \& Sakimoto (1992). Perirenal fat had a higher concentration of saturated fatty acids $(14: 0,16: 0$, 18:0) than backfat, and a lower concentration of monounsaturated fatty acids, such as $16: 1 \mathrm{n}$ 7 and 18:1n-9.

The basal daily diet contained about $7.5 \mathrm{~g} \mathrm{n}-3$ PUFAs, while $50 \mathrm{ml}$ cod liver oil contained $13.6 \mathrm{~g}$ n-3 PUFAs. The daily amount of EPA plus DHA was $1.3 \mathrm{~g}$ and $11.2 \mathrm{~g}$, respectively.
Daily supplementation of $50 \mathrm{ml}$ cod liver oil during the fourth and third week before slaughter led to a 1.4 to 1.7 times increase in the contents of n-3 PUFAs in muscles and fat depots. There was no difference between the incorporation of n-3 PUFAs in dark and light muscles. Regarding the n-3 PUFAs pattern after fish oil supplementation in perirenal fat, our results agree with those of Irie \& Sakimoto (1992). Perirenal fat contained more EPA and DHA than backfat after cod liver oil supplementation. Furthermore, a similar trend was noted for DHA in the control group. The contents of the monounsaturated fatty acid $20: 1 \mathrm{n}-9$, which made up $13.3 \%$ of the fatty acids in cod liver oil, were higher in backfat than in perirenal fat. The distribution mechanisms of dietary fatty acids seemed to be different in the 2 fat depots. In growing rats, fed a high fat diet, fish oil limited the cell hypertrophy of retroperitoneal fat, but did not affect hyperplasia in the same tissue ( $\mathrm{Bel}$ zung et al. 1993). The preferential increase of n-3 PUFAs in the perirenal fat, found in our study, might therefore be due to a larger cell membrane area in this fat depot compared to the subcutaneous fat.

Since the industrial revolution the human consumption of $\mathbf{n}-3$ fatty acids has diminished as the intake of n- 6 fatty acids has increased. While the $n-6 / n-3$ fatty acid ratio in the diet was nearly 1 during the evolutionary period of the human genetic constitution (Leaf \& Weber 1987), it might exceed 9 in the Western societies today (Galli \& Simopoulos 1989). A recommended n-6/n-3 fatty acid ratio in dietary fats for human consumption today is about 4 (Galli \& Simopoulos 1989). The n6/n-3 fatty acid ratio found in muscle and fat tissues of pigs fed a standard pig mash, corresponded to the ratio of the diet, which was about 8. Koizumi et al. (1991) showed that wild pigs have a more favourable $n-6 / n-3$ fatty 
acid ratio than pen fed pigs. This study has clearly shown that it is possible to lower the n6/n-3 fatty acid ratio in both muscle and fat tissues from pigs by dietary means. One way to change the n-6/n-3 fatty acid ratio in pig mash, is to supplement with cod liver oil as used in this study, but one must have in mind that this could downgrade the sensoric score of pig meat products, if used in higher doses and until the day of slaughter (Øverland et al. 1992, Taugbøl 1993).

\section{Acknowledgements}

We wish to thank Harald Falck Løken, Dal Forsøksgård, for taking care of the pigs, Kari Feigenwinter, Department of Biochemistry, Physiology and Nutrition, and lab. ing. Asbjørg Flo, Peter Möller avd. av ORKLA A.S., for their help with preparations for and GC-analyses of the fatty acids in the tissue samples. We also wish to thank Prof. Nina Køpke Vøllestad, Jorid Thrane Stuenæs and Bjørg Ingrid Selberg, National Institute of Occupational Health, Oslo, for their professional assistance with the muscle fibre typing. We are very grateful to Prof. Arnfinn Aulie, Department of Biochemistry, Physiology and Nutrition, for his help and cooperation.

\section{References}

Allen E, Cassens RG, Bray RW: Comparative lipid composition of three porcine muscles. J. anim. Sci. 1967, 26, 36-40.

Belzung F, Raclot T, Groscolas R: Fish oil n-3 fatty acids selectively limit the hypertrophy of abdominal fat depots in growing rats fed high-fat diets. Amer. J. Physiol. 1993, 264, R1111-8.

Brooke $M H$, Kaiser KK: Three "myosin adenosin triphosphatase" systems: The nature of their $\mathrm{pH}$ lability and sulphydryl dependence. J. Histochem. Cytochem. 1970, 18, 670-672.

Folch J, Lees M, Sloane Stanley GH: A simple method for the isolation and purification of total lipids from animal tissues. J. Biol. Chem. 1957, 226, 497-509.

Galli C, Simopoulos AP: Dietary $\omega 3$ and $\omega 6$ Fatty Acids - Biological Effects and Nutritional Essentiality. Plenum, New York, 1989, 403-404.

Hand DJ, Taylor CC: Multivariate analysis of variance and repeated measures. Chapman \& Hall, London, 1991.
Irie M; Sakimoto M: Fat characteristics of pigs fed fish oil containing eicosapentaenoic and docosahexaenoic acids. J. anim. Sci. 1992, 70, 470-477.

Iritani $N$, Narita $R$ : Changes of arachidonic acid and n-3 polyunsaturated fatty acids of phospholipid classes in liver, plasma and platelets during fat manipulation. Biochim. Biophys. Acta 1984, 753, 339-349.

Kleinbaum DG, Kupper LL, Muller KE: Applied regression analysis and other multivariate methods. PWS-Kent Publishing Company, Boston, Massachusetts 1988.

Koizumi I, Suzuki Y, Kaneko JJ: Studies on the fatty acid composition of intramuscular lipids of cattle, pigs and birds. J. Nutr. Sci. Vitaminol. 1991, 37, 545-554.

Leaf A, Weber PC: A new era for science in nutrition. Amer. J. clin. Nutr. 1987, 45, 1048-1053.

Malmfors B, Lundström K, Hansson I: Fatty acid composition of porcine back fat and muscle lipids as affected by sex, weight and anatomical location. Swedish J. agric. Res. 1978, 8, 25-38.

Montgomery DC: Design and analysis of experiments (2. ed.). John Wiley \& sons, New York, New York, 1984.

Simopoulos AP: Omega-3 fatty acids in health and disease and in growth and development. Amer. J. clin. Nutr. 1991, 54, 438-463.

Taugbøl O: Omega-3 fatty acid incorporation in fat and muscle tissues of growing pigs, fed supplements of fish oil. J. Vet. Med. A 1993, 40, 93-101.

Villegas FJ, Hedrick HB, Veum TL, McFate KL, Bailey $M E$ : Effect of diet and breed on fatty acid composition of porcine adipose tissue, J. anim. Sci. 1973, 36, 663-668.

Vøllestad NK, Vaage O, Hermansen L: Muscle glycogen depletion patterns in type I and subgroups of type II fibres during prolonged severe exercise in man. Acta. physiol. scand. 1984, 122, 433-441.

$\emptyset$ verland $M$, Taugbøl $O$, Haug $A$, Larsen HJ, Sundstøl F: Effect of fish oil on growth performance, carcass characteristics, sensoric parameters, selenium and vitamin $E$ status and fatty acid composition of pigs, Abstract 121, Omega-3 fatty acids - Metabolism \& Biological effects, Symposium held September 15-19,1992, Oslo, Norway. 


\section{Sammendrag}

Fettsyresammensetningen i muskulatur og fettvev hos gris $i$ forhold til anatomisk lokalisering og etter tilskudd av tran.

Fra griser som var blitt fôret utelukkende på standard svinefôr, ble fettsyresammensetningen fra 3 ulike muskler, de mørke røde $m m$ adductores, den lyse $m$ longissimus lumborum og den røde $m$ psoas minor, og fett fra nyreregionen og underhudsfett unders $\emptyset \mathrm{kt}$. Innholdet av flerumettede fettsyrer fra både n-6 og n-3 seriene var høyere i mm adductores sammenlignet med $m$ longissimus lumborum. Perirenalt fett hadde et høyere innhold av de mettede fettsyrene (14:0,16:0 og 18:0), og et lavere innhold av de enumettede fettsyrene (16:1n-7 og 18:1n-9) enn underhudsfett.

Tilskudd av $50 \mathrm{ml}$ tran, rik på n-3 flerumettede fettsyrer, daglig fjerde og tredje uke før slakting førte til at innholdet av n-3 fettsyrer i muskulatur og fett $\varnothing \mathrm{kte}$ rundt $50 \%$. Innholdet av de flerumettede fettsyrene av n-3 serien $\emptyset$ kte likt $\mathrm{i}$ alle 3 typer muskler. Fett fra nyreregionen inneholdt mer 20:5n-3 (EPA) og 22:6n-3 (DHA) enn underhudsfett, men mindre 20:1n-9, selv om alle disse fettsyrene finnes i rikelige mengder i tran.

Forholdet mellom n-6 og n-3 fettsyrer ble redusert i alle anatomiske lokalisasjoner som ble unders $\emptyset \mathrm{kt}$.

(Received May 10, 1994; accepted November 10, 1994).

Reprints may be requested from:O. Taugbøl, Department of Biochemistry, Physiology and Nutrition, Norwegian College of Veterinary Medicine, P.O. Box 8146 Dep, N-0033 Oslo, Norway. 
